\title{
Tone, Syntax, and Prosodic Domains in Luganda
}

\author{
Larry M. Hyman \\ University of California, Berkeley
}

Francis X. Katamba

University of Lancaster

"The documentation of... descriptive generalizations is sometimes clearer and more accessible when expressed in terms of a detailed formal reconstruction, but only in the rare and happy case that the formalism fits the data so well that the resulting account is clearer and easier to understand than the list of categories of facts that it encodes.... [If not], subsequent scholars must often struggle to decode a description in an out-of-date formal framework so as to work back to... the facts.... which they can re-formalize in a new way. Having experienced this struggle often ourselves, we have decided to accommodate our successors by providing them directly with a plainer account." (Akinlabi \& Liberman 2000:24)

\section{Introduction}

Although the interaction between tone, syntax, and prosodic domains in Luganda has been well-worked, both by us and by others (see references), several colleagues have commented to us over the years how useful it would be if the essentials were all assembled in one place. This is our goal here. We begin by presenting an overview of the syntax-phonology interface in Luganda, synthesizing from our previous work. We then turn to relative and other subordinate clauses, where we address the questions of how the prosodic domains within them compare to those in main clauses and how they form prosodic domains with the constituents in a main clause. Our new observations will further confirm that the prosodic phonology of Luganda is among the most intricate and complex of any language. Since some of the facts do not directly fit into any preexisting formal theory of the syntax-phonology interface, we do as the above citation suggests and present the descriptive generalizations relatively 
informally via classical autosegmental tonal representations and rules. The outline of the paper is as follows:

$\S 2$. The lexical tone system

$\S 3$. The prosodic domains

§3.1. The tone group (TG): defined by L tone deletion (LTD)

§3.2. The clitic group (CG): defined by final vowel shortening (FVS)

\$3.3. The tone phrase (TP): defined by $\mathrm{H}$ tone anticipation (HTA)

\$3.4. Compounds and phrasal words: "rank-shift" effects

$\S 4$. Subordinate clauses

$\S 4.1$. Subject- and object relative clauses (SRC, ORC) sometimes marked

\$4.2. Temporal relative clauses

$\S 4.3$. Subject- and object clefts (S-cleft, O-cleft)

by $\mathrm{H}$ tone

$\S 4.4$. Other subordinate clauses

reduction (HTR)

$\S 5$. Conclusion

\section{The lexical tone system}

The basic elements of Luganda tonology reveal a "2-3-2 system", where $\mathrm{H}=$ high and $\mathrm{L}=$ low:

(1) level of tonal description

representation contrasts

a. underlying $/ \mathrm{H}, \varnothing /$ privative input

b. intermediate $\mathrm{H}, \mathrm{L}, \varnothing$ ternary

c. surface H, L binary

output

As seen, the tonal representations depend on the level of representation. Since the intermediate level refers roughly to the output of the lexical phonology, the three levels might be identified as morphophonemic, phonemic, and (systematic) phonetic. Although we show only $\mathrm{H}$ and $\mathrm{L}$ outputs, a restricted $\mathrm{HL}$ falling tone also exists (vs. LH rising, which the language prohibits), and a downstepped ${ }^{\downarrow} \mathrm{H}$ can result if one tone group ends with HL and the next begins with $\mathrm{H}$. The tonebearing unit is the mora.

As seen in (2), Luganda words with an underlying / $\mathrm{H} /$ obligatorily have a $\mathrm{H}$ to L pitch-drop: 
(2)

\begin{tabular}{|c|c|c|c|c|c|}
\hline & $\# \sigma^{\prime} s$ & unde & intermediate & output with $\% 1$ & $\ldots H \%$ \\
\hline t. & $1 \sigma$ & /ki-bé/ & ki-bê & kì-bê & 'jackal' \\
\hline \multirow[t]{2}{*}{. } & $2 \sigma$ & /ki-kópo/ & ki-kópò & ópò & 'cup' \\
\hline & & /ki-s & ki- & & 'log' \\
\hline & $3 \sigma$ & /ki-sásilo/ & ki-s & ló & 'rubbish' \\
\hline & & $/ \mathrm{ki}-$ & & & 'torn' (cl. 7 \\
\hline & 1 & /ki-bónelezo/ & ki-bónèlezo & kì-bónèlézó & 'punishmer \\
\hline & & /ki-begábega/ & ki-begábèga & kì-bègábègá & 'shoulder' \\
\hline
\end{tabular}

In the above and other examples, an acute (') accent indicates $\mathrm{H}$ tone, a grave (') $=\mathrm{L},\left(^{\wedge}\right)$ indicates a HL falling tone, and the absence of an accent indicates lexically toneless moras, which receive their tones postlexically. The words in (2) illustrate the major, but not all noun patterns. The nouns in (3) show that Luganda words which lack an underlying $/ \mathrm{H} /$ acquire $\mathrm{LH}^{\mathrm{n}}$ output tones at the phrase level:

$\begin{array}{lllll} & \text { \# syllables } & \text { underlying } & \text { intermediate } & \text { output: \%L ... H\% } \\ \text { a. monosyllabic } & \text { /ki-de/ } & \text { ki-de } & \text { kì-dé 'bell' } \\ \text { b. bisyllabic } & \text { /ki-tabo/ } & \text { ki-tabo } & \text { kì-tábó 'book' } \\ \text { c. trisyllabic } & \text { /ki-lagilo/ } & \text { ki-lagilo } & \text { kì-lágíló 'command' } \\ & \text { quadrisyllabic } & \text { /ki-sanilizo/ } & \text { ki-sanilizo } & \text { kì-sánílízó 'comb' }\end{array}$

The output forms in (2) and (3) show that the $\% \mathrm{~L} \ldots \mathrm{H} \%$ boundary tones link to moras as follows:

(4) a. $\% \mathrm{~L}$ links $\mathrm{L} \rightarrow \mathrm{R}$ on all toneless moras up to a $/ \mathrm{H} /$; if there is no $/ \mathrm{H} /$, it goes on the first mora

b. $\mathrm{H} \%$ links $\mathrm{R} \rightarrow \mathrm{L}$ on all toneless moras up to a $\mathrm{L}$; if the word ends $\mathrm{H}-\mathrm{L}$, $\mathrm{H} \%$ doesn't link

c. toneless words (in fact, phrases) acquire a $\mathrm{L}-\mathrm{H}^{\mathrm{n}}$ pattern (one $\mathrm{L}$, multiply branching $\mathrm{H}$ )

It should be noted that pre-pausal $\mathrm{H} \%$ is "optional", typically indicating "finality".

The verb paradigm in (5) shows the toneless verb root -sib- 'tie' occurring with a $/ \mathrm{H} /$ or $/ Ø /$ subject marker (SM) and a $/ \varnothing /$ object marker $(\mathrm{OM})$ : 
(5)

underlying intermediate output: \%L ...H\%
a. $\quad \mathrm{SM}=\varnothing \quad$ /a-sib-a/
a-sib-a
à-síb-á
's/he ties'
b. $\mathrm{OM}=\varnothing \quad$ /a-ki-sib-a/
a-ki-sib-a
à-kí-síb-á
's/he ties it'
c. $\mathrm{SM}=/ \mathrm{H} / \quad /$ bá-sib-a/
bá-sìb-a
bá-sìb-á
'they tie'
d. $\quad \mathrm{OM}=\varnothing \quad /$ bá-ki-sib-a/
bá-kì-sib-a
bá-kì-síb-á
'they tie it'

The corresponding forms in (6) involve the /H/ verb root -láb- 'see':

(6)

underlying intermediate output: \%L ... H\%
a. $\quad \mathrm{SM}=\varnothing \quad$ /a-láb-a/
a-láb-à
à-láb-à
's/he sees'
b. $\mathrm{OM}=\varnothing \quad$ /a-ki-láb-a/
a-ki-láb-à
à-kì-láb-à 's/he sees it'
c. $\quad \mathrm{SM}=/ \mathrm{H} / \quad /$ bá-láb-a/
bá-làb-a
bá-làb-á 'they see'
d. $\quad \mathrm{OM}=\varnothing \quad$ /bá-ki-láb-a/
bá-kí-láb-à
bá-kí-láb-à 'they see it'
$\begin{array}{llll}\mathrm{H} & \mathrm{H} & \mathrm{H} & \mathrm{L}\end{array}$

The following is seen from the verb paradigm in (6): (i) When there is a /H-Ø$\mathrm{H} /$ sequence, a $\mathrm{H}$ tone plateau is formed to derive $\mathrm{H}-\mathrm{H}-\mathrm{H}$, as in (7a). (ii) When there is a $/ \mathrm{H}-\mathrm{H} /$ sequence, this becomes H-L by Meeussen's Rule where, as seen in (7b), $\mathrm{H} \rightarrow \mathrm{L}$, not Ø:

a. $\quad \mathrm{H}$ tone plateauing $(\mathrm{HTP})$<smiles>C=CC</smiles>

b. Meeussen's Rule (MR)

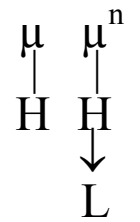

e.g. /bá-láb-a/ $\rightarrow$ bá-làb-a

An additional rule needed for some of the forms in (6) is L tone insertion (LTI): If after the application of HTP and MR there is no L, insert a $\mathrm{L}$ after the last $\mathrm{H}$ : /a-láb-a/ $\rightarrow$ a-láb-à 's/he sees', /ki-bónelezo/ $\rightarrow$ ki-bónèlezo 'punishment'.

As formulated in (7b), MR creates most of the intermediate Ls and the "globality problem": the L from MR remains distinct from Ø. This is seen in (8), where the $\mathrm{H} \%$ boundary tone links to the three final toneless moras, but not to the preceding three $\mathrm{L}$ moras which derive from $/ \mathrm{H} /$ :
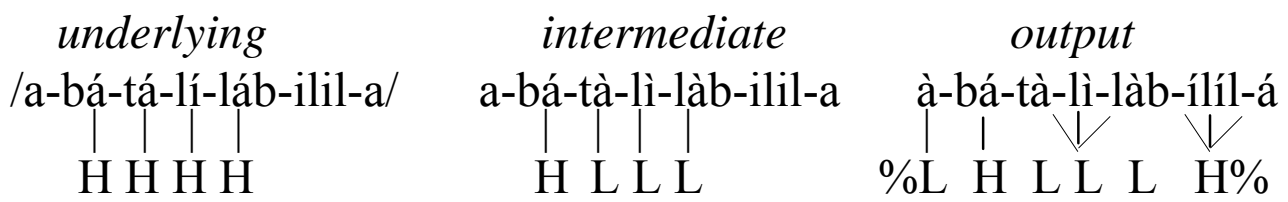

'they who will not look after' $\left(F_{2}=\right.$ general future $)$ 
The derivational account in (9) starts with a suffixal /H/ linked from the second to final mora of the verb stem and shows the interaction of MR, LTD, and HTP:

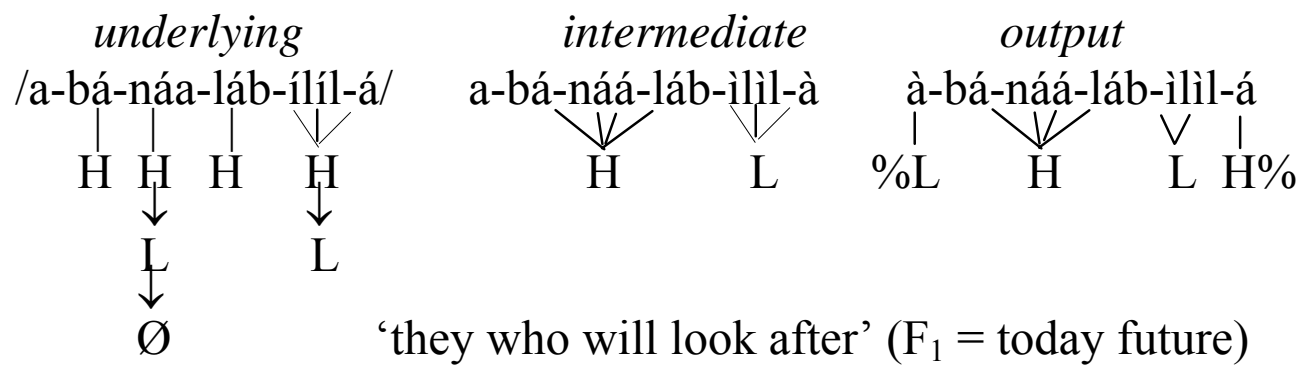

As seen, after MR applies, an additional rule is needed to delete a $\mathrm{L}$ tone which occurs between Hs:

$$
\text { L tone deletion (LTD) : } \quad \mathrm{L} \rightarrow \varnothing / \mathrm{H}-\mathrm{H}
$$

This is followed by HTP, and the assignment of boundary tones at the phrase level.

The above summarizes the lexical tone system which predicts that the "intermediate" representation of a word should not have the following properties:
a. a L before a H : but cf. bà-àkà-síbá 'they have just tied'
b. exactly two H moras in sequence : but cf. mù-wálábù 'an Arab'
c. an all H word: but cf. Wá-ngó 'Mr. Leopard'

As seen, there are exceptions: (11a) results from a rule of $\mathrm{H}$ tone reduction (HTR) discussed in $\S 4.1$. A relatively small number of nouns have two $\mathrm{Hs}$ in a row (cf. mù-góbâ 'driver'), while personifications involving the /wa-/ prefix are best analyzed with a preceding toneless floating mora, e.g. / $\mu$ wa-ngo/. The lexical tonology predicts that the following should also not occur:
a. a H without a following L : but cf. /a-sib-a/ $\rightarrow$ à-síb-á 's/he ties' (with \%L ... H\%)
b. a L without a preceding $\mathrm{H}$ : but cf. $\quad / a-s i b-a / ~ \rightarrow$ à-sìb-à (\%L without $\mathrm{H} \%$ )
c. a H-L-H sequence : but cf. /bá-sib-a/ $\rightarrow$ bá-sìb-á 'they tie' (with ... H\%)

As seen, the $\% \mathrm{~L} \ldots \mathrm{H} \%$ boundary tones render opaque three of the output generalizations from the lexical tonology, including the prohibition against a $\mathrm{H}-$ $\mathrm{L}-\mathrm{H}$ sequence within a word. In the next section we will see that H-L-H is sometimes prohibited even across words. 


\section{The prosodic domains}

In this section we discuss three prosodic domains: the tone group, the clitic group, and the tone phrase.

\subsection{The tone group (TG)}

As seen in the following examples, LTD (10) and HTP (7a) also apply postlexically:

(13) LTD and HTP also apply postlexically (italics = post-verbal focus)
a. báálàbà + kibê $\rightarrow$ báálábá kíbê 'they saw a jackal' $\left(\mathrm{P}_{2}\right)$
b. báálàbà + kikópò $\rightarrow$ báálábá kíkópò 'they saw $a$ cup'
c. báálàbà + kisikî $\rightarrow$ báálábá kísíkî 'they saw a log'
d. báálàbà + kisásìlo $\rightarrow$ báálábá kísásiló 'they saw rubbish'

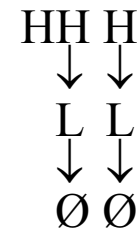

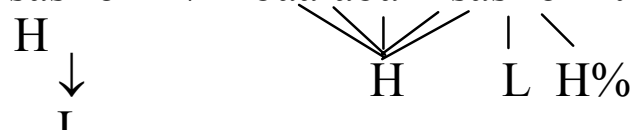
$\varnothing \varnothing \quad$ (we indicate a single tone under báá- for graphic convenience)

In (13) both the verb and the following object have a lexical $\mathrm{H}$ to $\mathrm{L}$ pitch drop. When they are concatenated, however, the verb undergoes MR, loses its Ls and a $\mathrm{H}$ plateau spans the two word sequence. which forms a tone group (TG). The sentences in (14a-d), where $\varnothing$ indicates a deleted $\mathrm{L}$, show that a TG can be formed between the verb and different kinds of complements within the same clause (in the $\mathrm{P}_{2}$ the prefixal /H/ is on /-á-/, hence /tu-á-/ $\rightarrow$ tw-aá- $\rightarrow$ tw-áá-):

a. tw-áá-génd-á tútùtú

$\mathrm{H} \quad \varnothing \quad \varnothing \quad \mathrm{HLH} \%$

b. tw-áá-génd-á lúlî

$\begin{array}{llll}\mathrm{H} & \varnothing & \varnothing & \mathrm{HL}\end{array}$

c. tw-áá-génd-á ná= wálúsìmbí

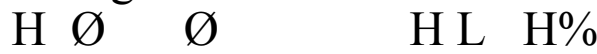

d. tw-áá-láb-w-á wálúsìmbí HØ $\varnothing \quad \mathrm{HL} \quad \mathrm{H} \%$

vs. e. tw-áá-mù-làb-à wàlúsìmbí $\mathrm{H} \quad \mathrm{L}$ L L $\mathrm{HL} \quad \mathrm{H} \%$

f. *tw-áá-mú-láb-á wálúsìmbí $\mathrm{H} \quad \varnothing \varnothing \varnothing \quad \mathrm{HL} \mathrm{H} \%$ 'we went slowly' $\left(\mathrm{P}_{2}\right)$

'we went the day before yesterday'

'we went with Walusimbi'

'we were seen by Walusimbi'

'we saw him, Walusimbi' 
The sentence in (14e) consists of two TGs, since the noun object is a rightdislocation falling outside the main clause. (14f) is thus ungrammatical.

The TG, which has parallels in related Bantu languages, e.g. tone reduction in Haya, and is reiminscent of "conjoint" verb forms in others (Cibemba, Citonga, Kirundi etc.), is defined as in (15).

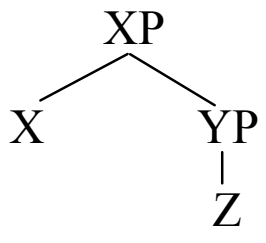

$$
\begin{aligned}
& \text { where: } \text { (i) } X \neq[+ \text { FOCUS }] \\
& \text { (ii) } Z \neq[+ \text { AUGMENT }] \\
&(\mathrm{Z}=\text { a phonological word }(\mathrm{PW}))
\end{aligned}
$$

While X must be the head of XP, Z need not be the head of YP, only the first word. As indicated, $X$ must not have an intrinsically focused value for tenseaspect-mood-polarity. Most affirmative verb forms are [-F] and form a TG with

\begin{tabular}{|c|c|c|c|}
\hline & affirmative & negative & \\
\hline & tú-láb-á wálúsìmbí & tè-tú-làb-à wàlúsìmbí & 'we (don't) \\
\hline & & & se \\
\hline \multirow[t]{2}{*}{ ERF } & tú-láb-yé wálúsìmbí & tè-tú-láb-yé wàlúsìm & t) \\
\hline & Н Ø $\varnothing \quad$ H LH\% & {$[\%$} & \\
\hline & tw-áá-láb-yéwálúsìmbí & tè-twáá-làb-yè wàlúsìmb & ، \\
\hline & H ØØ & $\% \mathrm{~L}$ & \\
\hline & tw-áá-láb-á wálúsìmbí & tè-twáá-làb-à wàlú & 'we \\
\hline & Ø H L H\% & $\% \mathrm{~L}$ & \\
\hline \multirow[t]{2}{*}{$F_{1}$} & tú-náá-láb-á wálúsìmbí & tè-tú-ú-láb-è wàlú & 'w \\
\hline & $\varnothing \quad \mathrm{H} \mathrm{L} \mathrm{H} \%$ & $\% \mathrm{~L}$ & won \\
\hline \multirow[t]{2}{*}{$\mathrm{F}_{2}$} & válúsìmbí & válú & 'we will \\
\hline & $\mathrm{H} \mathrm{L} \mathrm{H} \%$ & $\%$ L H L L & \\
\hline \multirow[t]{2}{*}{ NARR } & nè tú-láb-á wálúsìmb & tú-tà-làb-à wàlú & ‘\& we saw / \\
\hline & $\mathrm{H}$ & $\%$ & \\
\hline & b-é wálúsìmt & [no neg & 'let's see W.' \\
\hline & & -lém- & \\
\hline
\end{tabular}
what follows; negatives are $[+\mathrm{F}]$ and do not form a TG:

(The $\mathrm{F}_{2}$ negative shows $\mathrm{H}$ tone anticipation from Walúsìmbí onto the verb—see $\S 3.3$ below.)

The "inherently focused" or [+F] affirmative verb forms in (17) do not form a TG with what follows: 
(17)

IMPER làb-ílìl-à wàlúsìmbí \%L HL L H L H\%

t-ó-làb-ìlìl-à wàlúsìmbí

'(don't) look

H L L L L H L H\% after W.'

PERS tú-kyáá-láb-à wàlúsìmbí tè-tú-kyáá-láb-à wàlúsìmbí 'we (don’t) $\mathrm{H} \quad \varnothing \quad \mathrm{H} \quad \mathrm{L} \quad \mathrm{HL} \mathrm{H} \%$ \%L H $\quad \varnothing \quad \mathrm{H} \quad \mathrm{L} \quad \mathrm{H} \mathrm{L} \mathrm{H} \%$ still seeW.'

INCEP tw-ààkà-láb-à wàlúsìmbí tè-tú-nná-láb-à wàlúsìmbí 'we have(n't)

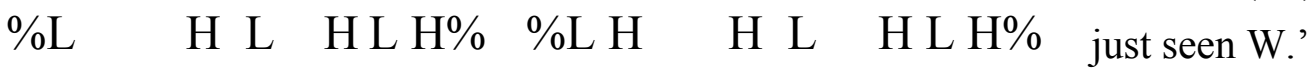

INF ò-kù-láb-à wálúsìmbí ò-bù-tá-làb-à wàlúsìmbí 'to (not)

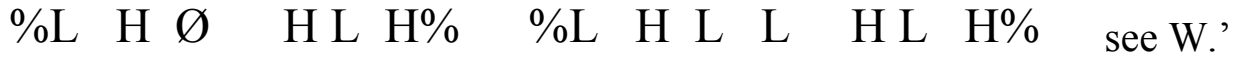

In $(18 \mathrm{~b}, \mathrm{c})$ a minimal pair is presented between the homophonous $[+\mathrm{F}]$ plural imperative vs. [-F] hortative, both from /mu-lab-é/:
a. $/$ mu-lab-é/ $\rightarrow$ mù-làb-ê
'see (pl.)!'
(L from LTI)
b. mù-làb-é wàlúsìmbí
‘see (pl.) Walusimbi!’

$\% \mathrm{~L}$ H́L H L H\%

c. (yàyágàlà) mù-làb-é wálúsìmbí '(he wanted) you (pl.) to see W.' $\mathrm{H} \varnothing \mathrm{H} \mathrm{L} \quad \mathrm{H} \%$

Besides $[+\mathrm{F}]$, the second property that can block $\mathrm{TG}$ formation in (15) is a [+AUGMENT] designation on $\mathrm{Z}$. This is clearly seen where the $[+\mathrm{A}]$ is expressed with the "initial vowel" (IV) augment on Z:
"even focus"
"post-verbal focus"
a. bá-làb-á é-bí-kópò
bá-láb-á bí-kópò
'they see cups/cups'
b. bá-làb-á ó-bú-sáàlé
bá-láb-á bú-sáàlé
'they see arrows/arrows'
c. bá-làb-á á-bá-sáwò
bá-láb-á bá-sáwò
'they see doctors/doctors'
$\mathrm{H}$ L
$\mathrm{H} \mathrm{L}$
$\mathrm{H} \varnothing$
$\mathrm{H} \mathrm{L}$

Although, as seen in (19), [-A] often correlates with post-verbal focus in the affirmative, negatives also require [-A], but do not form a TG with the verb:
a. tè-bá-làb-à bì-kópò
'they don't see the cups'
*è-bì-kópò
b. tè-bá-làb-à bù-sáàlé
'they don't see the arrows'
*ò-bù-sáàlé
c. tè-bá-làb-à bà-sáwò
$\begin{array}{llllllll} & \mathrm{L} & \mathrm{L} & \mathrm{H} & \mathrm{L}\end{array}$
'they don't see the doctors' *à-bà-sáwò

The table in (21) summarizes the three out of four possible combinations of $[ \pm \mathrm{A}]$ and $[ \pm \mathrm{LTD}]$ for 'they (do not) see cups' (the unmarked vowels in the top right cell receive $\mathrm{H}$ tone from the phrasal rule of $\mathrm{H}$ tone anticipation): 
(21)

\begin{tabular}{|c|c|c|c|}
\hline & $\mathrm{Z}=[-\mathrm{A}]$ & $\mathrm{Z}=[+\mathrm{A}]$ & \\
\hline & tè-bá-làb-à bì-kópò & bá-làb-a a-bi-kópò & TGs \\
\hline & bá-láb-á bí-kópò & $*$ & $=1 \mathrm{TG}$ \\
\hline
\end{tabular}

In (22) we summarize the conditions on $[ \pm \mathrm{A}]$. The crucial point is that $[-\mathrm{A}]$ needs special licensing, hence having an IV is more common than not:

(22) a. There are two [-A] licensers: NEG (negation) and FOC (focus)

b. NEG and FOC have scope only over what follows the verb

c. [-A] is well-formed only if it is licensed by NEG or FOC

d. $[+\mathrm{A}]$ is well-formed only if it is not so licensed

As a result, nouns are [+A] in citation: e-bi-kópò 'cups', o-bu-sáàle 'arrows', aba-sáwò 'doctors'. However, in a main clause, when there is either an implicit copula, as in (23a), or an overt copula as in (23b), the noun occurs without an augment by virtue of being in focus. In a relative clause, however, post-verbal focus does not occur, and the noun occurs with an augment, as in (23c).

(a)

$$
\begin{aligned}
& \text { 'they are } \\
& \text { bi-kópò } \\
& \text { bu-sáàlé } \\
& \text { ba-sáwò }
\end{aligned}
$$

(b) 'they were by-áá-lí bí-kópò bw-áá-lí bú-sáàlé bá-á-lí bá-sáwò $\mathrm{H} \varnothing \quad \mathrm{H}$ L (c) 'the ones which were __' e-by-áá-lì è-bì-kópò 'cups' o-bw-áá-lì ò-bù-sáàlé 'arrows' a-bá-á-lì à-bà-sáwò 'doctors'

The following additional points need to be made about the TG. First, $[ \pm \mathrm{A}]$ does not mean the same thing as presence vs. absence of the IV. Specifically, some IVs are not $[+\mathrm{A}]$ and some [+A]'s have no IV. The second point is that [+LTD] does not necessarily imply [-FOCUS]. Various word classes show that it is the $[+\mathrm{A}]$ that blocks LTD, not "even focus". First note in $(24 a, b)$ that before a name LTD does not apply in either a main clause negative (MCN) or relative clause negative $(\mathrm{RCN})$, which are $[+\mathrm{F}]$ :
a. te-bá-á-làb-à + walúsìmbì
$\rightarrow$ tè-bá-á-làb-à wàlúsìmbí 'they did not see W.' $\left(\mathrm{P}_{2}\right)$
b. a-bá-tá-á-làb-à + walúsìmbì
$\rightarrow$ à-bá-tá-á-làb-à wàlúsìmbí 'they who did not see W.'
c. bá-á-làb-à + wàlúsìmbì
$\rightarrow$ bá-á-láb-á wálúsìmbí 'they saw Walusimbi/Walusimbi' 

d. a-bá-á-làb-à + walúsìmbì
$\rightarrow$ à-bá-á-láb-á wálúsìmbí 'they who saw Walusimbi'

However, as seen in (24c), LTD does apply before a name in a main clause affirmative (MCA), whether the intention is even or post-verbal focus. Similarly, in (24d) LTD applies in a relative clause affirmative (RCA), where post-verbal focus is not possible. Similar LTD variation is seen with $/ \mathrm{na} / \sim / \mathrm{ne} /$ 'with' + NP independent of focus: no LTD in a MCN in (25a) or a RCN in (25b), LTD in a MCA independent of focus in (25c), LTD after a RCA verb where post-verbal focus is not possible in $(25 \mathrm{~d})$.
a. te-bá-á-gènd-à + na mu-kázì $\rightarrow$ tè-bá-á-gènd-à nà mù-kázì 'they did not go with a woman'
b. a-bá-tá-á-gènd-à + na mu-kázì $\rightarrow$ à-bá-tá-á-gènd-à nà mù-kázì 'they who did not go with a woman'
c. bá-á-gènd-à + ne ó-mu-kázì $\rightarrow$ bá-á-génd-á né ó-mú-kázì 'they went with a woman' bá-á-gènd-à + na mu-kázì $\rightarrow \quad$ bá-á-génd-á ná mú-kázì
d. a-bá-á-gènd-à + ne ó-mu-kázì $\rightarrow$ à-bá-á-génd-á né ó-mú-kázì 'they who went with a woman'

The last argument that LTD $\neq$ focus per se is that it also takes place within the noun phrase when a noun occurs in a compound or is possessed (the $\mathrm{L}$ tones from $\% \mathrm{~L}$ are not transcribed but can be inferred from their initial position):
a. N compound : mu-tém-à - bi-sikî $\rightarrow$ mutémá - bísíkî 'log-chopper'
b. $\mathrm{N}+$ poss. : e-bi-kópò byê $\rightarrow$ bi-kópó byê '(it's) his cups'
c. $\mathrm{N}+$ gen. : bi-kópò byaa= kinénè $\rightarrow$ bi-kópó byáá= kínénè

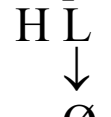
$\mathrm{H} \mathrm{L}$

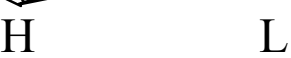
$\varnothing \quad$ '(it's) Kinene's cups'

As seen in (27), LTD does not occur when a noun is followed by a modifier, whether the latter begins with an IV or not:
a. adjectives
e-bi-kópò e-bi-nénè
'big cups'
b. numerals
bi-kópò bi-nénè
c. demonstratives:
e-bi-kópò bi-sátù
'they are big cups'
'three cups'
e-bi-kópò bi-lî
'those cups' 
Because of this, a verb + noun may form a TG, excluding a following modifier:

(28) a. tw-áá-làb-à bi-kópò bi-nénè $\rightarrow$ [tw-áá-láb-á bí-kópò $]_{\mathrm{TG}}$ bìnénè 'we saw big cups' $\quad \mathrm{H} \varnothing \varnothing \quad \mathrm{H} \underline{\mathrm{L}} \quad \mathrm{H} \mathrm{L}$

b. mu-wêndo gwaa= bi-kópò bi-nénè

[mu-wéndó gwáá= bí-kópò $]_{\mathrm{TG}}$ bìnénè '(it's) the price of big cups' HØ $\mathrm{H} \mathrm{L} \quad \mathrm{H} \mathrm{L}$

The TG thus cannot be said to be "edge-based" in the sense of including V+NP.

A TG can be formed consisting of several PWs, if each PW+PW satisfies the $\mathrm{X}-\mathrm{Z}$ condition in the configuration in (15):
a. [tw-áá-láb-á bí-kópó byáá= kínénè $]_{\mathrm{TG}}$
'we saw Kinene’s cups'

$\mathrm{H} \varnothing \quad \mathrm{H} \varnothing$

$\mathrm{H} \mathrm{L}$

b. [mu-wéndó gwáá= bí-kópó byáá= kínénè $]_{\mathrm{TG}}$ 'the price of the cups $\mathrm{H \varnothing}$ $\mathrm{H} \varnothing$ $\mathrm{H} \mathrm{L}$ of Kinene'

However, in a sequence of PWs which meet the X-Z criteria, an intervening toneless PW normally blocks LTD, e.g. /bi-tabo/ 'books' in (30).
a. [tw-áá-làb-à bi-tabo byaa $=$ kinénè $]_{\mathrm{TG}}$ $\mathrm{H}$ L L $\mathrm{H} \mathrm{L}$
'we saw Kinene's books'
b. $[\text { mu-wêndo gwaa }=\text { bi-tabo byaa }=\text { kinénè }]_{\mathrm{TG}}$ 'the price of Kinene's $\mathrm{H} \mathrm{L}$ books' HL

This shows that LTD is a "domain-juncture rule" as formulated in (31).

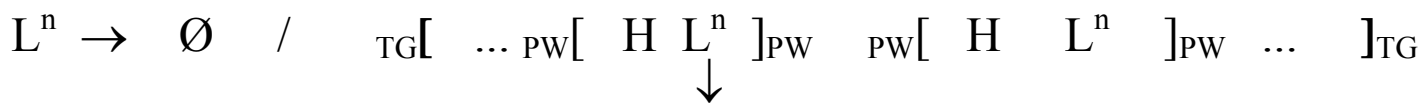

$$
\begin{aligned}
& \varnothing
\end{aligned}
$$

It should be noted, however, that for special emphasis some speakers allow LTD to apply across a (qualifying) toneless PW as a "domain-span rule":
a. normal: tw-áá-làb-à mùtúndá - bíkópò H L L
'we saw a cup-seller / a cup-seller'
b. emphatic:tw-áá-láb-á mútúndá - bíkópò
'we saw a cup-seller'

$$
\mathrm{H} \varnothing \varnothing \quad \mathrm{H} \mathrm{L}
$$

With the TG having been thus defined, we can now consider the clitic group. 


\subsection{The clitic group (CG)}

Like most (all?) other Bantu languages, Luganda has both proclitics and enclitics. Proclitics are mostly toneless, but differ in their tonal behavior from both toneless prefixes and PWs. Recall from (3) that the \%L ... H\% boundary tones map as $\mathrm{LH}^{\mathrm{n}}$ to a toneless word. In contrast, we see in (33) that \% links to any number of proclitics followed by the $\mathrm{LH}^{\mathrm{n}}$ realization of the toneless $\mathrm{PW}$ :
a. bà= mùlóndó
b. byàà $=$ bà $=$ mùlóndó
'the Mulondos' (Mulondo and his people)
c. kù $=$ byàà $=$ bà $=$ mùlóndó '(it's) those of the Mulondos'
d. nà $=$ kù= byàà $=$ bà= mùlóndó 'on those of the Mulondos'

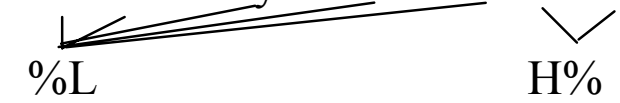 'and on those of the Mulondos'

There are at least two ways one can think of how to get the above outputs derivationally. The first is to let $\% \mathrm{~L}$ link iteratively to the first syllable after each left bracket, thereby leaving only the non-initial moras free to receive the $\mathrm{H} \%$ tone. The second is to let $\mathrm{H} \%$ link to as many moras as it can, with the stipulation that its first link cannot directly follow a left bracket. In this case the Ls which precede the $\mathrm{H}$ can be from $\% \mathrm{~L}$, as in $(33 \mathrm{~d})$, or from default $\mathrm{L}$ tone assignment. For our purposes it is enough to observe that proclitics work differently from (toneless) prefixes.

Proclitics also differ from PWs in that they are not subject to the processes of final vowel shortening (FVS), a subpart of which is formalized in (34).

(34) Final vowel shortening (FVS): $\quad \mathrm{VV} \rightarrow \mathrm{V} /{ }_{\mathrm{CG}}$ e.g. /o-ku-lí-a/ $\rightarrow$ o-ku-lí-à $\rightarrow$ o-ku-ly-áà $\rightarrow$ o-ku-ly-â 'to eat'

A vowel is shortened at the end of a CG, defined as [proclitics $=$ HOST $=$ enclitics]. We can see in $(33 \mathrm{c}, \mathrm{d})$ that the long vowel of the proclitic byaa= is preserved, since it not not CG-final.

Recall from (30) and (32a) that toneless PWs usually block LTD. In contrast, toneless proclitics are "invisible", as if forming PWs with their host:
a. tw-áá-láb-á byáá= wálúsìmbí
'we saw those of Walusimbi'

$$
\mathrm{H} \varnothing \varnothing
$$

$\mathrm{H} \mathrm{L} \quad \mathrm{H} \%$

b. tw-áá-génd-á ná= byáá= bá= wálúsìmbí 'we went with those of the

$\mathrm{H} \varnothing \varnothing$

$\mathrm{HL} \mathrm{H} \%$ Walusimbis' 
Turning to enclitics, all have an underlying / $\mathrm{H} /$. As seen in (36) multiple enclitics are also possible, which each preserving length on what precedes:
a. y-á-téés-éè $\rightarrow$ y-á-téés-ê
'he put' $\left(\mathrm{P}_{1}\right)$
b. y-á-téés-é kú= mú-pûnga mu= ki-bya
'he put some rice in the bowl'
c. $y$-á-kí-téés-éé $=$ mû $k u=$ mu-pûnga 'he put some rice in it'
d. $\quad$-á-kí-téés-éé $=$ múù $=k o ̂$ 'he put a little in it'
e. $\quad$-á-kí-téés-éé $=$ múù $=$ kóò $=$ kí 'what did he put a little of in?'

Н Ø Ø $\mathrm{H} \varnothing \quad \mathrm{HL}$ HL H

As seen in the above examples, the class 18 clitics $k u=$ and $=k 0$ are used to mark partitives. The sentence in (36e) shows that each of the enclitics preserves the length on the preceding syllable.

Another property of the $\mathrm{CG}$ is that it may not begin with a $\mathrm{H}$ tone vowel. The augment morpheme is a good place to observe this, since augments are all underlyingly $/ \mathrm{H} /$. As seen in (37a), the $\mathrm{H}$ is not realized CG-initially, but does surface after a proclitic:
a. /e-bi-tabo/ $\rightarrow$ è-bí-tábó 'books'
$\mathrm{H} \quad \% \mathrm{~L} \quad \mathrm{H} \%$
b. $/$ ne $=$ e-bitabo/ $\rightarrow$ né= é-bì-tábó 'with books'
$\mathrm{H}$
$\mathrm{H} \quad \mathrm{L} \quad \mathrm{H} \%$

In (38) we observe that the TG and CG potentially intersect, in violation of the Strict Layer Hypothesis:
a. one $\mathrm{TG}$, one $\mathrm{CG}$ :
tú-ly-áá $=$ kô
'we eat a little'
$\mathrm{H} \quad \varnothing \quad \mathrm{HL}$
b. two TGs, two CGs:
tè-tú-ly-à mù-pûngá $\% \mathrm{~L} \mathrm{H}$ L HL H\%
'we don't eat rice'
c. one TG, two CGs:
tú-ly-á mú-pûngá $\mathrm{H} \varnothing \quad \mathrm{HL} \mathrm{H} \%$
d. two TGs, one CG:

tè-tú-ly-àà =kô
$\%$ L H L HL
'we eat rice'
'we don't eat any'

As seen, both the CG and TG define domains just above the PW. The question is which, if either, is invoked in the formation of higher domains. The next higher prosodic domain, the tone phrase, is taken up in the next subsection. 


\subsection{The tone phrase (TP)}

In (39) we recapitulate the different sources we have seen of $\mathrm{H}$ and L:

(39) a. underlying $/ \mathrm{H}, \varnothing /$

b. Meeussen's Rule ( $7 b$ ) and $\mathrm{L}$ tone insertion produce Ls within the lexical word domain

c. LTD (10) removes Ls within both the lexical word and TG domains

d. $\% \mathrm{~L} \& \mathrm{H} \%$ boundary tones link to remaining peripheral toneless moras

This raises the question: What about remaining MEDIAL toneless moras? It turns out that PWs are grouped into tone phrases (TPs) defined by the rule of $\mathrm{H}$ tone anticipation (HTA) in (40).

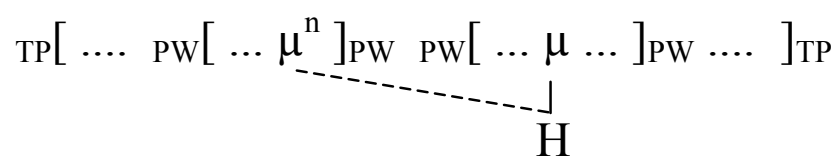

HTA affects any string of toneless moras, but must (i) cross a PW boundary, and (ii) leave at least one L mora behind:
a. a-bal-a e-bi-kópò $\rightarrow$ à-bál-á é-bí-kópò 's/he is counting cups' $\mathrm{H} \mathrm{L} \quad \% \mathrm{~L} \quad \mathrm{HL}$
b. bá-bàl-a e-bi-kópò $\rightarrow$ bá-bàl-á é-bí-kópò 'they are counting cups' $\mathrm{H} \mathrm{L} \quad \mathrm{H} \mathrm{L} \quad \mathrm{H} \mathrm{L} \quad \mathrm{H} \mathrm{L}$
c. à-bá-tà-lì-bàl-íl-á mú-límí bí-kópò 'they who will not count cups $\mathrm{H}$ L L L

In the above and subsequent examples, the toneless moras which undergo HTA are underlined. In $(41 \mathrm{a}, \mathrm{b})$ HTA takes place from one word onto the preceding, whereas in (41c) HTA goes through the toneless noun /mu-limi/ 'farmer' onto the preceding verb. HTA can in principle affect any number of toneless words.

It will have been noticed that (40) is formulated in terms of PWs, not TGs. The reason for this can be seen in the data in (42).
a. è-bì-kópò 'cups'
(*é-bí-kópò, *è-bí-kópò)
b. mù= bì-kópò 'in the cups'
(*mú= bí-kópò, *mù= bí-kópò)
c. bi-tabo $=$ kí $\rightarrow$ bì-tábó $=$ kí
'which cups?'
$\mathrm{H} \quad \% \mathrm{~L} \quad \mathrm{H}$
's/he counts a little'
d. $\quad$ a-bal-a $=$ kô $\rightarrow \quad$ à- $\underline{\text { bál-á }}=$ kô
$\mathrm{HL} \quad \% \mathrm{~L} \quad \mathrm{HL}$ 
(42a) shows that HTA will not apply word-internally, while (42b) shows that it also will not apply from a host onto a proclitic. It will, however, apply between an enclitic and its host, as in $(42 \mathrm{c}, \mathrm{d})$. It is for this reason that (40) must refer specifically to PWs. This raises additional difficulties for the notion of strict layering: Because of the intersection of TG and CG domains in (38), and with HTA having to be formulated as in (40), we can't even firmly establish a limited layering as in (43).

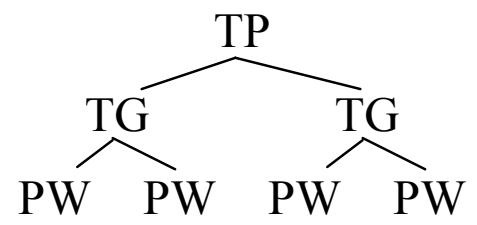

It will have been noticed that there is some similarity between HTA and the linking of $\mathrm{H} \%$. Both spread right to left, and both target toneless moras. The two are similar except that $\mathrm{H} \%$ delinks a word-final $\mathrm{L}$ if it is preceded by another $\mathrm{L}$ :

a. target word ends in $\mathrm{H}-\mathrm{L}$ sequence

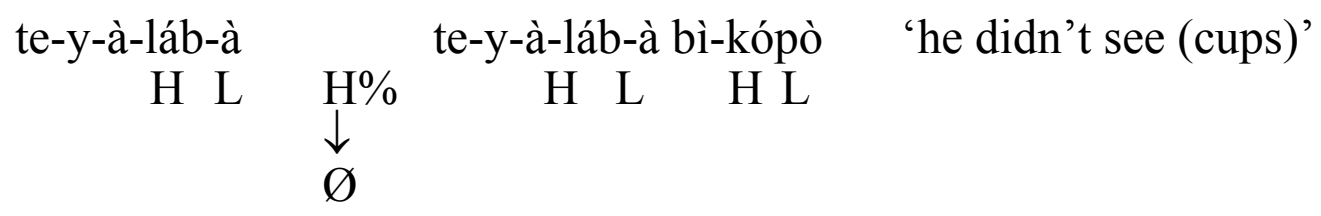

b. target word ends in H-L-L sequence

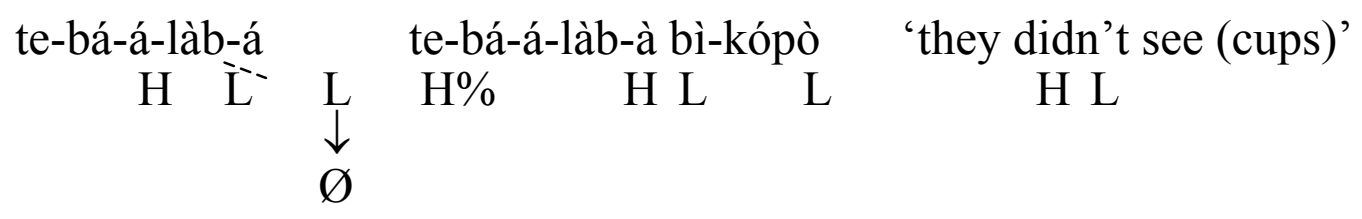

Finally, note that moras which fail to become $\mathrm{H}$ by HTP, HTA or $\mathrm{H} \%$ are pronounced $\mathrm{L}$, either by spreading a preceding $\mathrm{L}$ ( or $\% \mathrm{~L}$ ) or by default (both interpretations can work).

Let us now turn to the formation of TPs, where there is a basic left-right asymmetry. Major constituents which precede the verb constitute separate TPs, while those which follow the verb are grouped with the verb (and each other) as one TP:

$$
{ }_{T P}[X P]_{T P} \quad{ }_{T P}[X P]_{T P} \quad{ }_{T P}\left[\begin{array}{lllllllll}
V & X P & X P
\end{array}\right]_{T P}
$$

As seen in (46), there is no HTA from the verb onto the subject, an adverb, or a left-dislocation, whose toneless moras receive $\mathrm{L}$ tone 
(46)
a. à-bà-lìmì bá-á-làb-à mùlóndó $\mathrm{H} \%$
'the farmers saw Mulondo' $\% \mathrm{~L}$
$\mathrm{H} \mathrm{L} \mathrm{L}$
H\%

b. àmàngwààgò bá-á-làb-à mùlóndó 'suddenly they saw Mulondo' $\% \mathrm{~L}$ $\mathrm{H} \quad \mathrm{L} \quad \mathrm{L}$

$\mathrm{H} \%$
c. mùlòndò bá-á-mù-làb-á $\% \mathrm{~L} \quad \mathrm{H} \quad \mathrm{L} \quad \mathrm{L} \quad \mathrm{H} \%$
'Mulondo, they saw him'

d. àbàlìmì mùlòndò àmàngwààgò bá-á-mù-làb-á
$\% \mathrm{~L}$
$\mathrm{H} \quad \mathrm{L}$ L H\%

'the farmers, Mulondo, suddenly they saw him'
e. àbàlìmì wàlúsìmbì bá-á-mù-làb-á 'the farmers, Walusimbi, $\begin{array}{llllll}\% \mathrm{~L} & \mathrm{HL} & \mathrm{L} & \mathrm{H} & \mathrm{L} & \mathrm{L} \mathrm{H} \%\end{array}$

(46e) shows that there also is no HTA from Walúsìmbì onto the left-dislocated object, abalimi 'farmers'.

On the other hand, HTA applies from an object, adverb or right-dislocation onto the verb (and onto each other):
a. tè-bá-lì-yìmbá lú-yîmbá $\% \mathrm{~L} H \mathrm{~L}$ L HL $\mathrm{H} \%$
'they will not sing a song'
b. tè-bá-lì-yìmbá bú-bî $\% \mathrm{~L} \quad \mathrm{H} \mathrm{L} \mathrm{L}$
'they will not sing badly'
c. tè-bá-lì-lù-yìmbá á-bá-límí ó-lú-yîmbá 'they will not sing it, the
$\%$ L H L L L
$\mathrm{HL} \mathrm{H} \%$ farmers, the song'

Assuming that $\% \mathrm{~L}$ marks the left edge of a TP, there are two views on how TPs are built:
a. concatenated within IP
${ }_{\mathrm{IP}}\left[\quad \mathrm{TP}\left[\text { farmers }_{\mathrm{i}}\right] \mathrm{TP}_{\mathrm{TP}}\left[\text { Mulondo }_{\mathrm{j}}\right]_{\mathrm{TP}}\left[\text { they }_{\mathrm{i}} \text {-him }_{\mathrm{j}} \text {-saw }\right]\right]_{\mathrm{IP}}$
b. nested, right-branching ${ }_{\mathrm{TP}}\left[\right.$ farmers $_{\mathrm{i}} \quad \mathrm{TP}_{\mathrm{TP}}\left[\right.$ Mulondo $_{\mathrm{j}} \mathrm{TP}_{\mathrm{TP}}\left[\right.$ they $_{\mathrm{i}}$-him $_{\mathrm{j}}$-saw $\left.\left.]\right]\right]$

If the correct interpretation is nested domains, Luganda (and Kinande) become the opposite of Haya ( $\mathrm{S}=\mathrm{a}$ full sentence/assertion):
a. Luganda marks beginning of each $\mathrm{S}$ b. Haya marks end of each $\mathrm{S}$
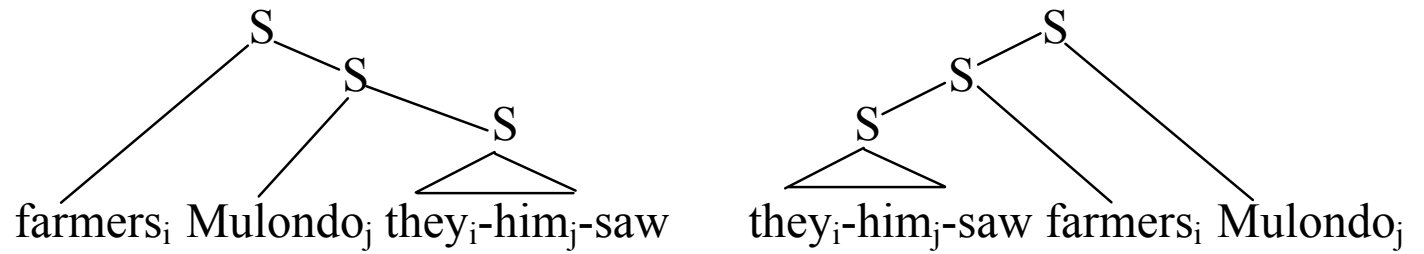
Recall from (27) that noun + modifier sequences do not form TGs. Most do form a TP, allowing HTA:
a. '(the) big books'
b. 'the three books'
c. 'those books'
è-bí-tábó é-bí-nénè
è-bí-tábó é-bí-sàtú
è-bí-tábó bí-lî
$\% \mathrm{~L}$
$\mathrm{H}$
L $\% \mathrm{~L}$
$\mathrm{H}$ L H\% \%L HL

Mysteriously, when they lack an IV, numerals pose a barrier to HTA: è-bì-tàbò bì-sátù 'three books' (cf. è-bí-tábó é-bí-sàtú 'the three books').

\subsection{Compounds and phrasal words}

Besides the possibly nested nature of the tonal domains, there also is the issue of recycling caused by "rank-shifting" which potentially arises when a phrase is treated as a syntactic word or $\mathrm{X}^{\mathrm{o}}$. Some English examples taken from the internet showing a phrase used as a noun or adjective are given in (51).

(51) a. He might take offense if some Johnny-come-lately thinks he can do a better job (= a noun)

b. His hail-fellow-well-met manner helped him to advance in the sales force. (= an adjective)

Both compounds and phrasal words of this sort are common in Luganda, and potentially interact with LTD (10), HTA (40), and FVS (34). Two types of productive formations are illustrated in (52) and (53).

(52) Agentive nominalization: $m u$-VERB- $a+$ noun (often plural) or infinitive

a. mulwa-kujjula 'woman slow to serve food' (lit. delayer + to serve)

b. mwásá - jjútè 'hard, uncomfortable chair' (lit. boil-breaker)

c. mutunda -bikópò 'cup-seller' (lit. seller + cups; -tund- 'sell')

d. mutémá - bísíkî 'log chopper’ (lit. chopper + logs; -tém- 'chop’)

$\mathrm{H} \varnothing \quad \mathrm{HL} \quad(=1 \mathrm{TG})$

(53) Instrumental nominalization: genitive $-a a=+$ infinitive + locative enclitic
a. kyaa $=$ kulábìra $=$ kô 'example'
(lit. 'that which to see from')

$\mathrm{HL} \quad \mathrm{HL}$

( $=2$ TGs, since an infinitive $=[+\mathrm{F}])$

b. $\quad$ kyaa $=$ kulandira $=$ kô

'trellis'

(lit. 'that which to creep on')

$\mathrm{HL}$

c. kyaa $=$ kutéèka $=$ mû bijanjaalo 'something to put beans in' $(=2 \mathrm{TGs})$

HL HL

(lit. 'that which to put beans in') 


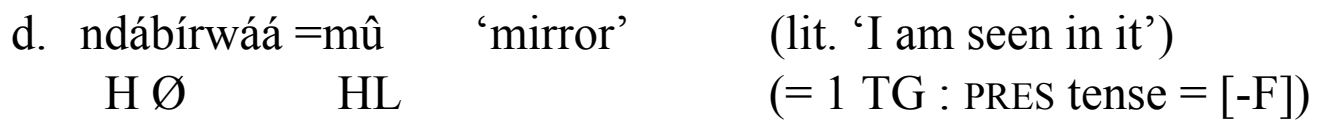

As seen, phrasal words form one vs. two TGs depending on the nature of the components, particularly if the verb form is $[+\mathrm{F}]$ or $[-\mathrm{F}]$. The following proper nouns consisting of a verb + complement are two TGs either because the verb is $[+\mathrm{F}]$ or, in the case of $(54 \mathrm{c})$, because the noun is $[+\mathrm{A}]$ :
a. sílìvá - kùno
(a name - lit. 'I will not leave here')
b. wáálábyèè $=\mathrm{kí}$
(a name - lit. 'what have you seen yet?')
c. túlíná - ómùbéèzí
(a name - lit. 'we have a helper')
$\mathrm{H}$ HL $\mathrm{HL} \mathrm{H} \%$
(the $\mathrm{L}$ of túlínâ is realized on [mù])

Names and other non-productive phrasal words consisting of a subject + verb are also necessarily two TGs:
a. mwáámì - àkóóyè 'easy-chair'
(lit. 'chief has tired')
b. kyáálà - kímpáddè 'thief'
(lit. 'fingernail has given me')
c. nsí - yàléètá
(a name )
(lit. 'country brought')
HL HL H\%

However, it should be noted that a SUBJ + VERB, which would be two TPs in a main clause, becomes one TP as a phrasal word. Thus, compare the following where HTA (40) applies only in (56b):
a. ò-mù-gènzì t-á-zz-ê ' $a /$ the traveler hasn't returned' $\% \mathrm{~L}$ $\mathrm{H} \quad \mathrm{HL}$
b. mùgénzí - tázzê 'a delinquent debtor' $\% \mathrm{~L}$ $\mathrm{H}$ HL

(2 TPs)

Finally, recall from (26) that a noun + possessor constitutes a single TG. Interestingly, with different speaker preferences, phrasal words with two TGs may become one TG when possessed:

(57) a. kyaa= kulábìra =kô 'example' (lit. that which to see from) kyàà= kùlábìrá $=$ kó kyê $\sim$ kyàà= kulábírá =kó kyê 'his/her $\mathrm{H} \underline{\mathrm{L}} \mathrm{H} \varnothing \mathrm{HL} \quad \mathrm{H} \underline{\varnothing} \mathrm{H} \varnothing \mathrm{HL}$ example’

b. mwáámì-àkóóyè 'easy chair' (lit. chief has tired) mwáámì-àkóóyé yáá= kínénè $\sim$ mwáámí-ákóóyé yáá= kínénè
$\mathrm{H} \underline{\mathrm{L}} \quad \mathrm{H} \quad \varnothing$
$\mathrm{H} \mathrm{L}$
$\mathrm{H} \underline{\varnothing} \quad \mathrm{H} \varnothing$
$\mathrm{H} \mathrm{L}$ 'Kinene's easy chair' 
In other words, because of the fact that a possessor normally "takes a noun", a possessed TG+TG phrasal word may be "rank-shifted" to a single TG as an $\mathrm{N}^{\mathrm{O}}$ would be expected to be.

\section{Subordinate clauses}

In this section we discuss the formation of prosodic domains in subordinate clauses. The questions that arise concerning such clauses are the following:

a. What is their relation to the TG?

i. internally: do their constituents divide up into $\mathrm{X}$ and $\mathrm{Z}$ as in main clauses? (Answer: yes)

ii. externally: does their first PW function as $\mathrm{Z}$ after a main clause verb? (Answer: yes and no)

b. What is their relation to the TP?

i. internally: do their pre-verbal constituents group into separate TPs? (Answer: no)

ii. externally: do they group into the same TP as the preceding main clause? (Answer: yes and no)

We begin with relative clauses, then move on to consider temporal clauses, clefts, and other subordinate clauses. Taken together, (56) shows 2 TPs $\rightarrow 1$ TP and (57) shows 2 TGs $\rightarrow 1$ TG.

\subsection{Subject- and object relative clauses}

In this section and $\S 4.3$ we discuss how relative clauses figure in the formation of TGs and TPs, respectively. Beginning with TGs, we illustrate with subject relative clauses $(\mathrm{SRCs})$ in $(59 \mathrm{a}, \mathrm{b})$ the fact that $[+\mathrm{A}]$ and $[+\mathrm{F}]$ block LTD within relative clauses exactly as in main clauses:

a. à-bà-kázì à-bá-á-làb-à è-bì-kópò
$\% \mathrm{~L} \quad \mathrm{H}$ H $\underline{\mathrm{L}} \underline{\mathrm{L}} \quad \mathrm{H}$ L

b. a-ba-kázì à-bá-tá-á-làb-à bì-kópò $\% \mathrm{H} \quad \mathrm{HL} \quad \mathrm{H} \quad \mathrm{H} \underline{\mathrm{L}} \underline{\mathrm{L}} \quad \mathrm{H} \mathrm{L}$

c. t-á-mányí bà-kázì bá-á-láb-á bí-kópò ‘ $\mathrm{H} \quad \mathrm{HL} \quad \mathrm{HL} \quad \mathrm{H} \varnothing \varnothing \quad \mathrm{H}$

d. à-mànyí bá-kázì bá-á-láb-á bí-kópò HØ $\mathrm{HL}$ HØ $\varnothing \quad$ H L 'the women who saw the cups $[+\mathrm{A}]^{\prime}$

'the women who didn't $[+F]$ see the cups'

'he doesn't know the women [-A] who saw the cups [-A]' 'he knows the women who saw the cups' 
In $(59 \mathrm{a}, \mathrm{b})$, which can also occur after à-mànyî 'he knows', we observe that unlike main clauses, SRCs can take an IV, here $a$-. As expected, the augment is missing after a negative verb in $(59 \mathrm{c})$ and when occurring in an NP under postverbal focus, as in (59d). LTD is thus free to apply.

While SRCs occur without an overt relativizer, non-subject relative clauses require an -e relativizer which occurs immediately before the verb. Examples of object relative clauses (ORCs) are seen in (60).

(60) a. tw-áá-gùl-à è-bì-kópò wàlúsìmbì byè y-à-léètá 'we bought the cups $\mathrm{H}$ L L H H H L L HL H\% that W. brought' b. tw-áá-gúl-á bí-kópò wàlúsìmbì byè y-à-léètá 'we bought the cups $\begin{array}{lllllll}\mathrm{H} \varnothing & \varnothing & \mathrm{H} L & \mathrm{HL} & \mathrm{L} & \mathrm{HL} \mathrm{H} \% & \text { that } W \text {. brought' }\end{array}$

In (60) the relativizer /bi-e/ [byè] agrees with the class 8 of the noun e-bi-kópò 'cups'. Since it must occur directly before the verb, we regard it as a syntactic clitic. However, since the vowel of byè is short, the non-subject relativizer/-e/ is not a phonological proclitic.

A rule not yet discussed, $\mathrm{H}$ tone reduction (HTR), optionally targets a SRC verb whose head is $[-\mathrm{A}]$ :
a. tú-làb-á á-bá-kázì à-bá-zìn-á $\mathrm{H} \mathrm{L}$
$\mathrm{HL} \quad \mathrm{H} \mathrm{L} \mathrm{H} \%$
b. tè-tú-làb-à bà-kázì bá-zìn-á $\% \mathrm{LH}$ L L H L H L H\%
c. tè-tú-làb-à bà-kázì bà-zìn-â $\%$ L H L L $\quad$ H L L L HL

'we see the women $[+\mathrm{A}]$ who are dancing' (*à-bà-zìn-â)

'we don't see the women [-A] who are dancing'

'we don't see the women [-A] who are dancing'

(61a) shows a SRC with an augment on the verb after the affirmative verb. After a negative, the verb lacks an augment. The tones in (61b) are comparable to those in (61a), while those in (61c) have undergone HTR, which lowers a wordinitial sequence of Hs. The derivations we propose for $(61 \mathrm{~b}, \mathrm{c})$ are given in $(62)$.
a. normal realization [bá-zìn-à]b.

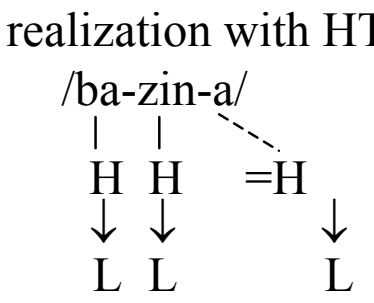
(HTR, LTI)
( $\rightarrow$ bá-zìn-á with $\mathrm{H} \%$ )

In (62a) the enclitic $=\mathrm{H}$ tone links to the final vowel, followed by two applications of MR. In (62b) HTR applies before the enclitic $=\mathrm{H}$ links. The result with LTI is a final HL falling tone. 
As now shown in (63), $\mathrm{H}$ tone reduction (HTR), also optionally targets an ORC verb whose head is $[-\mathrm{A}]$ :

(63) a. tú-gùl-á é-bí-kópò byè tú-làb-á 'we buy the cups [+A] that we see' $\mathrm{H} \mathrm{L} \quad \mathrm{HL} \quad \mathrm{H} \mathrm{L} \mathrm{H} \% \quad$ (*tù-làb-â)

b. tè-tú-gúl-á bì-kópò byè tú-làb-á 'we don’t buy the cups [-A] that $\% \mathrm{~L} \mathrm{H} \quad \mathrm{HL} \quad \mathrm{HL} \quad \mathrm{H} \mathrm{L} \mathrm{H} \%$ we see' (from tú-làb-à $+\mathrm{H} \%$ )

c. tè-tú-gúl-á bì-kópò byè tù-làb-â 'we don't buy the cups [-A] that $\% \mathrm{LH}$ HL H L L L HL we see'

The same HTR variations are observed on a headless SRC verb in (64) and on a headless ORC verb in (65).
a. tú-làb-á á-bá-zìn-á $\mathrm{H} \mathrm{L}$ $\mathrm{H} \quad \mathrm{L} \mathrm{H} \%$
b. tè-tú-làb-à bá-zìn-á \%LH L L H L H\%
c. tè-tú-làb-à bà-zìn-â \%L H L L L L HL

(65) a. tú-gùl-á byé tú-làb-á $\mathrm{H} \mathrm{L} \quad \mathrm{H} \quad \mathrm{L} \mathrm{H} \%$

b. tè-tú-gúl-á byè tú-làb-á $\% \mathrm{LH} \quad \mathrm{HL} \quad \mathrm{H} \quad \mathrm{L} \mathrm{H} \%$

c. tè-tú-gúl-á byè tù-làb-â $\% \mathrm{LH} \quad \mathrm{HL} \quad \underline{\mathrm{L}} \mathrm{HL}$ 'we see the ones $[+\mathrm{A}]$ who are dancing' (*à-bà-zìn-â)

'we don't see the ones [-A] who are dancing' (from bá-zìn-à $+\mathrm{H} \%$ )

'we don't see the ones [-A] who are dancing' (with HTR)

'we buy the ones $[+\mathrm{A}]$ that we see' (*tù-làb-â)

'we don't buy the ones [-A] that we see' (from tú-làb-à $+\mathrm{H} \%$ )

'we don't buy the ones [-A] that we see' (with HTR)

Turning now to how relative clauses participate in TG formation, note in (66) that LTD can take place between the main verb, the /-e/ complementizer, and the relative verb:

(66) a. tú-gùl-á byé tú-làb-á 'we buy the ones that we see [+A]'

$\mathrm{H} \mathrm{L} \quad \mathrm{H} \mathrm{L} \mathrm{H} \%$ = even focus (with HTA)

b. tú-gúl-á byé tú-làb-á 'we buy the ones that we see [-A]'

$\mathrm{H} \varnothing \quad \mathrm{H} \mathrm{L} \mathrm{H} \%$ = post-verbal focus (with LTD, HTP)

c. tú-gúl-á byé tú-láb-â 'we buy the ones that we see [-A]'

$\mathrm{H} \varnothing \quad \varnothing \varnothing \mathrm{HL} \quad$ = post-verbal focus (with HTR, LTD, HTP)

LTD does not apply in (66a) since the ORC is [+A] (as can be seen from the even focus interpretation). With post-verbal focus the ORC becomes [-A] and LTD is observed straightforwardly in (66b). LTD also applies in (66c) where the 
ORC first undergoes HTR to become tù-làb-â via HTR followed by LTD and HTP.

\subsection{Temporal relative clauses}

Although we have thus far exemplified /-e/ only with ORCs, the same complementizer is used for any non-subject relative clause (NSRC), including temporal clauses relativized on unexpressed head nouns, e.g. lu-nákù 'day' (class 11):
a. tw-áá-bùùz-á lwè y-à-gwâ $\mathrm{H} \quad \mathrm{LL}_{\mathrm{L}} \mathrm{H}^{-} \mathrm{L}$ b. tw-áá-búúz-á lwè y-à-gwâ $\mathrm{HL}$
c. tw-áá-búúz-á lwé y-á-gwâ Н ØØ Ø $\mathrm{HL}$
'we asked (on) the day he fell' [+A] HL
'we asked when (they day) he fell' $[-\mathrm{A}]$
'we asked for the day he fell' $[-\mathrm{A}]$

In $(67 \mathrm{a}, \mathrm{b})$ the floating $\mathrm{H}$ of /'lu-e/ links to the final vowel of the verb which otherwise would have ended with a $\mathrm{L}$ derived by MR. The $\mathrm{L}$ of lwè results from LTI. As seen, LTD applies in (67b). In (67c) HTP occurs throughout the sentence (making it hard to verify that the floating $\mathrm{H}$ is present). A number of grammatical morphemes in Luganda are preceded by a floating H. Another is the 'near speaker' demonstrative /'-nò/ 'this/these' which is inherently [-A]:

(68) a. LTD after an affirmative verb with either even or post-verbal focus

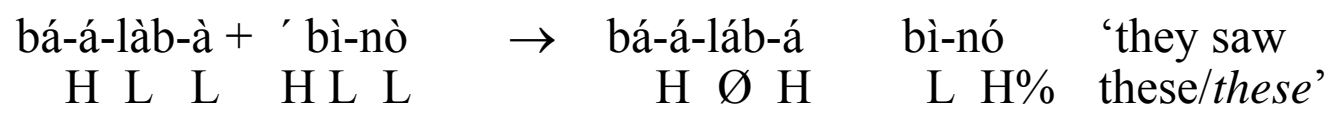

b. no LTD after a negative verb te-bá-á-làb-à + ' bì-nò $\rightarrow$ tè-bá-á-làb-á bì-nó 'they did not see

c. no LTD after $[+\mathrm{A}]$ relative clause verb which assigns $[+\mathrm{A}]$ a-bá-á-làb-à + ' bì-nò $\rightarrow$ à-bá-á-làb-á bì-nó
H L L 'they who saw

As seen in $(68 \mathrm{a}), / /^{\prime}$-nò/ is not capable of being $[+\mathrm{A}]$ in main clause affirmatives, whether with even or post-verbal focus. Hence LTD applies. LTD fails to apply in (68b) since the verb is negative. The surprise is (68c), where we see that /'-nò/ is capable of being [+A] when following a $[+\mathrm{A}]$ relative clause affirmative. There thus are two issues concerning grammatical morphemes: Which have a preceding floating $\mathrm{H}$ and how do they function with respect to $[ \pm \mathrm{A}]$ ? 
Up until now the element $Z$ in (15) has belonged to the same clause as the preceding verb. Although proper nouns such as Walúsìmbì obligatorily condition LTD as object of the verb, we see in (69a) that LTD does not apply when Walúsimbì is the subject of a relative clause under even focus:

(69) a. y-à-génd-à wàlúsìmbì lwè y-á-jj-à 'he left the day Walusimbi came' $\% \mathrm{~L} \quad \mathrm{H} \quad \mathrm{L} \quad \mathrm{HL} \quad \mathrm{L} \quad \mathrm{H} \quad \mathrm{L}$

b. y-à-génd-á wálúsìmbì lwè y-á-jj-à 'he left the day Walusimbi came' $\% \mathrm{~L} \quad \mathrm{H} \quad \varnothing \quad \mathrm{HL} \quad \mathrm{L} \quad \mathrm{H} \quad \mathrm{L}$

Since LTD does apply in (69b) under post-verbal focus, we can assume that the subject of the relative clause, here Walúsimbì, has undergone a raising process to occur as a sister to the verb. The same contrast is seen with bwè 'when, how', relativized on the head noun bûddè 'time' (class 14):

(70) a. tw-áá-sèk-à wàlúsìmbì bwè y-à-zín-à 'we laughed when H L L H L L $\quad$ H L Walusimbi danced'

b. tw-áá-sék-á wálúsìmbì bwè y-á-zín-à 'we laughed only when/at the $\mathrm{H} \quad \varnothing \quad \varnothing \quad \mathrm{HL} \quad \mathrm{L} \quad$ H L way Walusimbi danced'

Finally, consider the following sentences which have a temporal adverb:
a. à-láb-à è-bì-kópò jjô byè tw-áá-gùl-á $\% \mathrm{~L} \mathrm{H} \mathrm{L}$
$\mathrm{H}$ L HL
$\mathrm{H} \quad \mathrm{L} \mathrm{H} \%$
's/he sees the cups that yesterday we bought'

b. à-láb-à jjó byè tw-áá-gùl-á 's/he sees what yesterday we bought $\% \mathrm{~L} \mathrm{H} \mathrm{L} \mathrm{HL}$ $\mathrm{H} \quad \mathrm{L} \mathrm{H} \%$

c. à-láb-á jjó byè tw-áá-gùl-á 's/he sees what yesterday we bought $\% \mathrm{~L} \mathrm{H} \varnothing \mathrm{HL}$ $\mathrm{H} \quad \mathrm{L} \mathrm{H} \%$

As seen in (71a), although jjô 'yesterday' clearly goes with the relative clause, if occurring before the relativized verb, it must also precede the relativizer (*byè jjô). Under even focus in (71b), LTD does not apply between the main clause verb and the $[+\mathrm{A}]$ adverb jjô. Crucially, (71c) shows that LTD does apply before [-A] adverb jjô under post-verbal focus, which, recall, originates in the relative clause. The conclusion in unmistakable: Raised elements from a relative clause can serve as $\mathrm{Z}$ in TG formation. This possibility accounts also for how LTD potentially distinguishes between direct and indirect questions: 
(72) a. y-à-búùz-à àní gwè w-à-láb-à 'he asked who you saw' $\% \mathrm{~L}$ HL L HL H L

b. y-à-búúz-á ání gwè w-à-láb-à 'who did he ask that you saw?' $\% \mathrm{~L}$ HØ $\varnothing \mathrm{HL} \quad \mathrm{H}$ L 'he asked who you saw'

In (72a), where LTD doesn't apply, anî 'who' must belong to the lower clause, hence an indirect question. In (72b), where LTD does apply, anî either belongs to the upper clause, forming a direct question, or it belongs to the lower clause as an indirect question under post-verbal focus.

\subsection{Subject and object clefts}

To some extent clefts resemble relative clauses, but there are also some important differences. In order to appreciate the comparision, note first that unlike main clauses, HTA applies from the verb onto the subject of a SRC:
a. à-bà-lìmì bá-á-zìn-á $\% \mathrm{~L}$
$\mathrm{H} \quad \mathrm{L} \mathrm{H} \%$
'the farmers danced' $\quad(=2$ TPs $)$
b. à-bá-límí á-bá-á-zìn-á $\% \mathrm{~L}$ $\mathrm{H} \mathrm{L} \mathrm{H} \%$
'the farmers who danced' $\quad(=1 \mathrm{TP})$

Similarly, HTA applies through the /-e/ complementizer onto the relativized noun of an ORC/NSRC, as in (74a).
a. à-bá-límí bé tw-áá-làb-á $\% \mathrm{~L}$ $\mathrm{H} \mathrm{L} \mathrm{H} \%$
'the farmers that we saw'
b. à-bá-límí wálúsìmbì bè y-a-láb-à 'the farmers that Walusimbi saw' $\% \mathrm{~L} \quad \mathrm{H} \mathrm{L} \mathrm{L} \quad \mathrm{HL}$

In addition, (74b) shows that HTA applies from the subject of a relative clause onto the relativized noun. Consider now the sentences in (75).

(75) a. te-bá-bál-á bì-kópò byè tù-làb-â 'they don't count the cups that

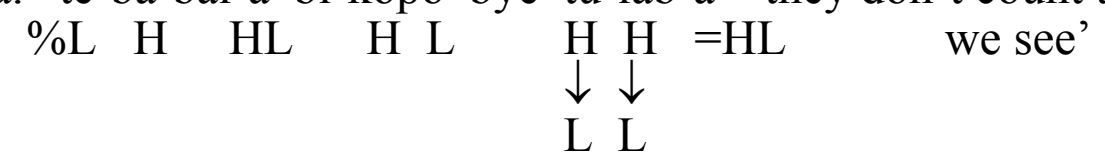
b. te-bá-bál-á bì-tábó byé tú-láb-â 'they don't count the books $\% \mathrm{~L} \quad \mathrm{H} \quad \mathrm{HL} \quad \cdots . . . . . \mathrm{L}, \mathrm{L} \Lambda$ that we see'

In (75a) HTR applies to the [-A] relative verb, which is realized L-L-HL. HTR also applies in (75b), but this time the enclitic $=\mathrm{H}$ is able to trigger HTA right 
through the L tones created by HTR and onto the toneless PW /bi-tabo/ 'books'. We know that HTR has applied in (75b) because of the final HL of tú-láb-â, as we saw in (62b). As a result of such forms, we have to revise HTA: the H is anticipated onto preceding toneless moras across a PW in the TP, even through L tones from HTR. In other words, the only thing that stops HTA is a L (or sequence of Ls) which is preceded by a $\mathrm{H}$ or is TP-initial.

We are now prepared to compare clefts and relative clauses. In (76a) we recall that an ORC forms a single TP with HTA applying from the verb onto a toneless relativized noun:
a. ò-mú-límí gwé bá-làb-á $\% \mathrm{~L}$ $\mathrm{H} \quad \mathrm{L} \quad \mathrm{H} \%$
b. mù-lìmì gwè $\% \mathrm{~L}$

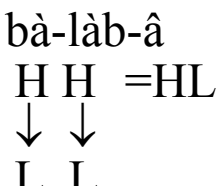

'the farmer that they see'

(from bá-làb-à $+\mathrm{H} \%$ )

'it's a farmer that they see'

As seen in (76b), the same /-e/ relativizer is used in non-subject (e.g. object-) clefts, which however require HTR. Since HTA does not apply across the derived $\mathrm{L}$ tones as in (75b), the resulting structure constitutes two TPs, i.e. much like a main clause. A similar contrast between a non-subject relative vs. cleft is seen in (77).
a. wànò wè tú-bá-súz-à [ wàlúngì $\% \mathrm{~L} \mathrm{~L} \quad \mathrm{H} \quad \mathrm{H} \quad \mathrm{L} \quad \% \mathrm{LH}$ L
$\mathrm{b}$ wànò wè tù-bà-súz-à

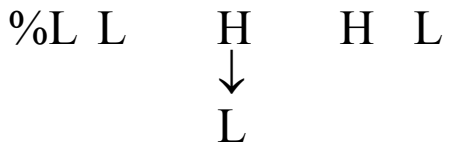
'here where we house them is nice' 'it's here that we house them'

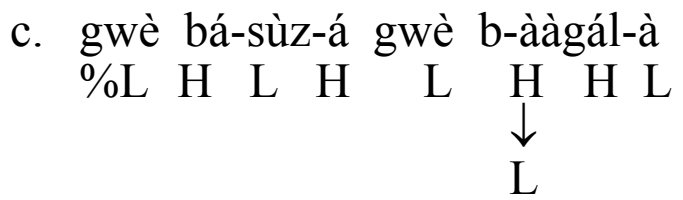

'it's the one they house that they want'

Again, HTR does not apply to the relative clause in (77b), but does apply to the non-subject cleft in (77b). (77c) shows a succession of a headless non-subject relative clause followed by a non-subject cleft. Appropriately, HTR applies only to the latter part of the sentence.

There is one exception to the above generalization: WH-clefts do not undergo HTR. Thus compare the following, where HTR does not apply in (78b). 
(78)
a. bá-láb-á ání
'who do they see?' (lit. they see who?)
H $\varnothing \quad \mathrm{H}$
b. àní gwè bá-làb-à 'who do they see?' (*àní gwè bà-làb-â) $\%$ L H L H L L

(76b) also has no $\mathrm{H} \%$ since the latter marks finality and this is a question.

Contrasting with their non-subject counterparts, subject-clefts do not undergo HTR:
a. bà-lìmì bèè= bá-zìn-á
'it's the farmers who are dancing' $\% \mathrm{~L}$
$\mathrm{H} \quad \mathrm{L}$ H\%
(*bè̀ $=$ bà-zìn-â)

b. bì-kópò byèè= bí-náá-gw-â 'it's cups that will fall'
$\% \mathrm{~L} \mathrm{H} \mathrm{L}$
$\mathrm{H} \varnothing \quad \mathrm{HL}$
(*byèè = bì-nàà-gw-â)

Another difference with non-subject relative and cleft clauses is that the relativizer /-e/ is a phonological proclitic. In this case, when /bi-e/ becomes byèè $=$ it keeps its length.

\subsection{Other subordinate clauses}

In the preceding subsections we have briefly treated relative, temporal relative, and cleft clauses. In this section we continue with a few more clause types. The first concerns clauses with /'nga/ 'while'. As seen in (80), the subject may precede or follow /'nga/, whose floating $\mathrm{H}$ may condition LTD, as appropriate:

(80) a. tw-áá-tùùk-á ngà à-bà-lìmì bá-yìmb-á 'we arrived while the

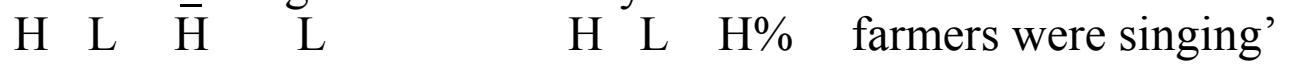

b. tw-áá-tùùk-à à-bá-límí ngà bá-yìmb-á (= same)

$$
\mathrm{H} \mathrm{L} \mathrm{L} \mathrm{H} \text { L H L } \mathrm{H} \%
$$

c. tw-áá-túúk-á ngà à-bà-lìmì bá-yìmb-á 'we arrived while the

$\mathrm{H} \varnothing \varnothing \mathrm{HL} \quad \mathrm{H} \mathrm{L} \quad \mathrm{H} \%$ farmers were singing'

d. tw-áá-túúk-á à-bà-lìmì bá-yìmb-á (= same)

HØØ $\mathrm{HL} \quad \mathrm{H} \mathrm{L} \quad \mathrm{H} \%$

e. tw-áá-túúk-á à-bá-límí ngà bá-yìmb-á (= same)

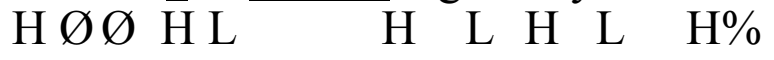

In (80a), the floating $\mathrm{H}$ of /'nga/ delinks the final L of tw-áá-tùùk-à, while in (80b) the underlined moras of toneless a-ba-limi have undergone HTA triggered by the floating H. (80c) is the same as (80a) except that LTD has applied on the matrix verb, indicating post-verbal focus. (80d) is the same as (80c) except that $n g a$ has been deleted. (80e) is particularly intriguing as it has a floating $\mathrm{H}$ both 
before and after a-ba-limi, as if there were two nga's, the first of which is deleted. Alternatively, when a-ba-limi is raised between the floating $\mathrm{H}$ and /nga/, it splits the H in two!

We have already seen that other grammatical morphemes have a preceding floating $\mathrm{H}$ which enters into the phrasal tonology. Sometimes this floating $\mathrm{H}$ can "travel", as in the case of /'bùlì/ 'every':
a. tè-y-à-túùk-à $\rightarrow$ tè-yà-túùk-á bùlì lùnákù 'he didn't arrive $\% \mathrm{~L} \quad \mathrm{HL} \quad \mathrm{L} \quad \% \mathrm{~L} \quad \mathrm{HL} \overline{\mathrm{H}}$ L L $\mathrm{H} \mathrm{L}$ every day'
b. tè-y-à-túùk-à nà= mù-límí $\% \mathrm{~L} \quad \mathrm{HL} \quad \mathrm{L} \quad \mathrm{H} \%$ 'he didn't arrive with
c. tè-y-à-túùk-à nà= byàà $=$ mù-límí $\% \mathrm{~L} \quad \mathrm{HL} \quad \mathrm{L}$ a farmer'
d. tè-y-à-túùk-á nà= byàà= bùlì mù-límí 'he didn't arrive with those
$\% \mathrm{~L} \quad \mathrm{HL} \mathrm{H}$ L $\mathrm{H} \%$ of every farmer' 'he didn't arrive with those of the farmer'

As seen in (81a), the floating $\mathrm{H}$ of /' bùlì/ delinks the $\mathrm{L}$ of the final -à of the verb. There also is no HTA onto prenominal bùlì, suggesting that both moras must have a L tone, perhaps from MR (vs. a final Ø). The sentences in $(81 \mathrm{~b}, \mathrm{c})$ are designed to show that the toneless proclitics $n a=$ and byaa $=$ do not place a $\mathrm{H}$ tone onto the preceding verb. However, in (81d) we see that when bùlì is present, it triggers a final $\mathrm{H}$ on the verb - even if at some distance!

Moving on to other subordinate clause types, we see in (82a) that the subjunctive verb paradigm appears to be subject to initial HTR:
a. y-à-yágàl-à tù-làb-é mùlóndó
$\% \mathrm{~L}$ H L L L L HL
$\mathrm{H} \%$
'he wanted us to see Mulondo'
b. yà- $\%$

$$
\begin{aligned}
& \text { HL } \quad \mathrm{H} \% \\
& \mathrm{HL}
\end{aligned}
$$$$
\begin{aligned}
& \mathrm{L} \\
& \downarrow \\
& \downarrow
\end{aligned}
$$$$
\text { ('that we see Mulondo') }
$$$$
\text { 'he wanted us to see Mulondo' }
$$$$
\text { ('that we see Mulondo') }
$$$$
\varnothing \varnothing
$$

As seen in (82b) there may be HTA from the subjunctive verb onto what precedes (again crossing the L tones from HTR). In addition, some speakers allow the subject of a subjunctive clause to condition LTD, as appropriate:
a. y-a-yágàl-à wàlúsìmbì à-jj-ê $\%$ L H L L H L L HL
'he wanted Walusimbi to come'
b. y-a-yágál-á wálúsìmbì à-jj-ê
('that Walusimbi come') $\% \mathrm{LH} \varnothing \varnothing \quad \mathrm{HL} \quad \mathrm{L} \quad \mathrm{HL}$
'he wanted Walusimbi to come'
('that Walusimbi come') 
Finally, let us briefly consider complement clauses which are introduced by /'nti/ 'that, namely'. These have the same properties as main clauses:
a. y-à-gâmb-á ntì à-bà-lìmì bá-á-gùl-à è-bí-tábó
$\% \mathrm{~L} \mathrm{HL} \quad \mathrm{H} \mathrm{L} \quad \mathrm{H}$ L L $\quad \mathrm{H} \%$
'he said that the farmers bought books'
b. t-á-kkírìz-à lù-gámbó ntì à-bà-lìmì bá-á-f-à
$\mathrm{H}$ HL L $\mathrm{H} \mathrm{L} \quad \mathrm{H} \mathrm{L}$
'he doesn't believe the rumor that the farmers died'

In both sentences the subject /a-ba-limi/ remains all $\mathrm{L}$ in the 'that' clause. While /'nti/ has a floating $\mathrm{H}$ which goes onto the verb in (84a) and onto the toneless noun /lu-gambo/ 'rumor' in (84b), there is some variation between /nti/ and /'nti/, the latter potentially conditioning LTD:
a. y-à-gâmb-à ntì bá-á-gw-à 'he said that they fell' (no floating H) $\% \mathrm{~L}$ HL L
(floating $\mathrm{H}$ )
b. y-à-gâmb-á ntì bá-á-gw-à (=same) $\% \mathrm{~L} H \mathrm{HL} \quad \mathrm{H} \quad \mathrm{L} \quad \mathrm{H} \quad \mathrm{L}$
c. y-à-gámb-á ntì bá-á-gw-à 'he said that they fel' (floating H+LTD) $\% \mathrm{~L}$ HØ $\mathrm{H} \quad \mathrm{L} \quad \mathrm{H} \quad \mathrm{L}$

The complementizer $m b u$, which introduces reported hearsay ('apparently, people say') shows the same properties as nti.

\section{Conclusion}

The above completes our "tutorial" on tone, syntax and prosodic domains in Luganda - as far as we have been able to take it to date. While we skipped many of the finer points of our previous studies, the basics have been presented in enough detail to appreciate the complexity of the system as well as the outstanding problems which must still be resolved. In presenting the data we have taken the liberty of presenting words without showing vowel coalescences which occur on $\mathrm{V} \# \mathrm{~V}$ sequences across words. We also have not discussed the role of pauses and the different "intonemes" which mark the ends of intonational phrases and utterances. A rough approximation of the intonemes which may be superimposed on output tones is given in (86). 
(86)
a. $\mathrm{H} \%$ : finality
d. ${ }^{\uparrow} \mathrm{HL} \% \quad$ : exclamative $\left({ }^{\uparrow} \mathrm{H}=\right.$ superhigh $)$
b. L\% : non-finality
e. ${ }^{\uparrow} \mathrm{H} \%$ : yes-no interrogative
c. LH\%: paused list
f. $\varnothing \mathrm{H} \%$
: WH interrogative $(\varnothing=$ loss
of final HL pitch drop)

However, the above is only tentative. A more definitive statement must await further detailed investigation.

\section{References}

Akinlabi, Akinbiyi \& Mark Liberman. 2000. The tonal phonology of Yoruba clitics. In B. Gerlach and J. Grizjenhout (eds). Clitics in phonology, morphology and syntax. Amsterdam: Benjamins, 31-62

Ashton, E.O. et al. 1954. A Luganda grammar. London: Longmans, Green and Co.

Cole, Desmond T. 1967. Some features of Ganda linguistic structure. Johannesburg: Witwatersrand University Press.

Heny, Frank. 1974. Ganda tone as "pitch accent. Ms. University of Massachusetts, Amherst.

Hyman, Larry M. 1982. Globality and the accentual analysis of Luganda tone. Journal of Linguistic Research 1, 1-40.

Hyman, Larry M. 1988. Direct vs. indirect syntactic conditioning of phonological rules. Proceedings of E.S.C.O.L. 1987. Ohio State University, 147-163.

Hyman, Larry M. \& Francis X. Katamba. 1990. Final vowel shortening in Luganda. Studies in African Linguistics 21, 1-59.

Hyman, Larry M. \& Francis X. Katamba. 1990-91. The augment in Luganda tonology. Journal of African Languages and Linguistics 12, 1-45.

Hyman, Larry M. \& Francis X. Katamba. 1993a. A new approach to tone in Luganda. Language 69, 34-67.

Hyman, Larry M. \& Francis X. Katamba. 1993b. The augment in Luganda: syntax or pragmatics? In Sam Mchombo (ed.), Theoretical aspects of Bantu grammar. Stanford: C.S.L.I, 209-256.

Hyman, Larry M. \& Francis X. Katamba. 1999. The syllable in Luganda phonology and morphology. In Harry van der Hulst \& Nancy Ritter (eds), The syllable: views and facts. Berlin: Mouton de Gruyter, 349-416.

Hyman, Larry M. \& Francis X. Katamba. 2005. The word in Luganda. In F. K. Erhard Voeltz (ed.), Studies in African linguistic typology. Amsterdam: Benjamins, 171-193.

Hyman, Larry M., Francis X. Katamba \& Livingstone Walusimbi. 1987. Luganda and the strict layer hypothesis. Phonology (Yearbook) 4, 87-108. 
Katamba, Francis X. 1974. Aspects of the grammar of Luganda. Doctoral dissertation, University of Edinburgh.

Katamba, Francis X. \& Larry M. Hyman. 1991. Nasality and morpheme structure constraints in Luganda. Africanistische Arbeitspapiere 25, 175-211.

Klavans, Judith L. 1985. The independence of syntax and phonology in cliticization. Language 61, 95-120.

Nespor, Marina \& Irene Vogel. 1986. Prosodic phonology. Dordrecht: Foris.

Pak, Marjorie. 2008. The postsyntactic derivation and its phonological reflexes. Doctoral dissertation, University of Pennsylvania.

Selkirk, Elisaberth O. 1984. Phonology and syntax: The relation between sound and structure. Cambridge, Mass.: MIT Press.

Stevick, E. W. 1969. Pitch and duration in Ganda. Journal of African Languages 8, 1-28.

Tucker, A.N. 1962. The syllable in Luganda: A prosodic account. Journal of African Languages 1, 122-166.

Walusimbi, Livingstone. 1996. Relative clauses in Luganda. Köln: Rüdiger Köppe Verlag. 